\title{
Profitable rabi Crops in Red Sandy Loam Soils of North-Coastal Zone of Andhra Pradesh, India
}

\author{
T.S.S.K. Patro ${ }^{1 *}$, P. Jamuna ${ }^{2}$, N. Anuradha ${ }^{3}$ and D. Nagarjuna ${ }^{4}$ \\ ${ }^{1}$ (Plant Pathology), ${ }^{3}$ (Plant Breeding), ${ }^{4}$ (Agronomy), OFR, Agricultural Research Station, \\ Vizianagaram, A.P., India \\ ${ }^{2}$ Regional Agricultural Research Station, Anakapalle, A.P., India \\ *Corresponding author
}

\section{Keywords}

Rabi crops, Cost

economics, Profitability,

Red sandy loam soils, NC

Zone

\section{Article Info}

Accepted:

04 October 2018

Available Online:

10 November 2018

\section{A B S T R A C T}

Field studies were conducted at Agricultural Research Station (ARS), Vizianagaram in red sandy loam soils during rabi 2017-18 with different crops viz., finger millet (variety, Sri Chaitanya), horse gram (variety, VZM-1) and sunnhemp (variety, SH-4). Cost economics was worked out to study the suitability of different rabi crops based on their profitability. In case of horse gram, effect of different dates of sowing was also studied by following the sowing window from September $2^{\text {nd }}$ fortnight to November $2^{\text {nd }}$ fortnight (Four dates of sowing, replicated five times) to study the yield performance in relation to weather parameters. The experimental results indicated that the benefit: cost ratio was found to be more with sunnhemp (2.42:1) followed by horse gram (1.90:1) and finger millet (1.76:1). Finger millet recorded higher net returns (Rs.28,137/ha) as compared to that of sunnhemp (Rs.24,732/ha) and horse gram (Rs.10,700/ha). Since, finger millet is a climate resilient crop; yield variability is less affected when compared to the crops like sunnhemp and horse gram. This was evidently reported in another field study conducted on performance of horse gram with different dates of sowing during rabi 2017-18 which indicated that the early sown (second fortnight of September, 2017) as well as the late sown (first fortnight of November, 2017) horse gram crop recorded lower yields (3.51 and 3.46q/ha, respectively) when compared to the yields recorded $(5.65 \mathrm{q} / \mathrm{ha})$ in second fortnight of October, 2017 due to congenial soil moisture with favourable weather parameters like rainfall, relative humidity and temperatures prevailed during crop growth period in October sown horse gram crop. The early sown horse gram crop had taken long time for maturity (100 days) due to prolonged vegetative growth with the receipt of high rainfall $(233.4 \mathrm{~mm})$ in the early stage of crop growth (September second fortnight) and the late sown horse gram crop (first fortnight of November, 2017) got subjected to soil moisture stress coupled with less relative humidity at the time of grain development (second fortnight of January, 2018) that caused forced maturity taking only 81 days crop duration. Hence, the present study revealed good profitability with the bonus crops like sunnhemp and horse gram and higher net returns with finger millet in rabi season.

\section{Introduction}

North-Coastal (NC) Zone is the extreme Northeast of Andhra Pradesh State and consisting of three North Eastern coastal districts viz., Srikakulam, Vizianagaram and Visakhapatnam. The Vizianagaram district of North Coastal Zone falls under 18.4 AgroEcological Sub-Region (ICAR) with Geographical Co-ordinates of $17^{0} 7^{1} \mathrm{~N}$ 
Latitude, $83^{0} 25^{1} \mathrm{E}$ Longitude and $73 \mathrm{~m}$ altitude. Majority of the soils are red sandy loams occupying $37 \%$ of the cultivated area and the soils are light textured, low in organic matter content and poor in water and nutrient holding capacity. The predominant farming situation in the district is rainfed - red sandy loams (1, 50,172 ha) growing, in general, with paddy as major crop in kharif season. The irrigation sources are rainfed dependent canals $(30.8 \%)$, tanks (53.4\%) and open wells (13\%); while the source of irrigation through bore well/tube well is $12.6 \%$ only. The annual rainfall of the district is $1121.9 \mathrm{~mm}$ having high relative humidity.

The majority $(61.7 \%)$ of rainfall is received through South-West monsoon (692.7 mm) (June to October) and only $21.9 \%$ rainfall $(245.9 \mathrm{~mm})$ is in North-East monsoon. Since, assured irrigation facilities are very meagre in the district, farmers have been confined to growing crops like rice fallow pulses in rainfed areas which often results in poor yields due to more prone to pest and diseases like YMV, powdery mildew and terminal moisture stress and crops like maize, ground nut, sugar cane under limited irrigation facilities giving less economic returns due to poor yields.

Hence, the present study was taken up with different rabi crops that can fit into the predominant farming situation of rainfed- red sandy loamy soils of the district with an aim of selecting suitable rabi crop that could fetch higher net returns. The crops like finger millet (Eleusine coracana L.), a climate resilient crop (Gupta, S.M. et al., 2017), horse gram (Macrotyloma uniflorum), a drought tolerant hardy crop (Dorian Q. Fuller and Charlene Murphy, 2018) and sunnhemp (Crotalaria juncea), a crop with minimal input requirement and large demand as green manure seed (Jamuna, 2018) were selected and cost economics was worked out in the present study.

\section{Materials and Methods}

Field studies were conducted at Agricultural Research Station, Vizianagaram in red sandy loam soils during rabi 2017-18 with different crops viz., finger millet (variety, Sri Chaitanya), horse gram (variety, VZM-1) and sunnhemp (variety, $\mathrm{SH}-4$ ). The soils are light textured, slightly acidic to neutral in soil reaction ( $\mathrm{pH} 6.3$ to 7.5 ), normal in electrical conductivity, low in soil organic carbon content, low in soil available nitrogen and medium to high in soil available $\mathrm{P}_{2} \mathrm{O}_{5}$ and $\mathrm{K}_{2} \mathrm{O}$. The availability of micronutrients is above critical level. Finger millet crop was sown adopting spacing of $30 \times 10 \mathrm{~cm}$ using seed rate of $10 \mathrm{~kg} / \mathrm{ha}$; while sunnhemp and horse gram were sown by broadcast adopting seed rate of $30 \mathrm{~kg} / \mathrm{ha}$ each. Fertilizers were applied to ragi crop only @ 60:40:30 kg N, P, $\mathrm{K} / \mathrm{ha}$, but no fertilizers were added to horse gram and sunnhemp. The average yield and yield attributes were recorded for different crops by computing the data from 6 replications of each crop and cost economics was worked out to study the suitability of different rabi crops based on their profitability.

Yield attributes were recorded by taking randomly five plants per plot and yield was recorded from $5 \mathrm{mx} 5 \mathrm{~m}$ sample size. In case of horse gram, effect of different dates of sowing was also studied by following the sowing window from September $2^{\text {nd }}$ fortnight to November $2^{\text {nd }}$ fortnight (Four dates of sowing, replicated five times). The crop in the respective dates of sowing was harvested at its maturity stage. Seed yield and crop duration (no. of days taken for maturity) in respective plots were recorded. The seed yield and crop duration of horse gram were related with different dates of sowing. Weather data recorded at Agricultural Research Station, Vizianagaram was utilised for interrelating the seasonal performance of horse gram. 


\section{Results and Discussion}

Yield and yield attributes were recorded in different rabi crops (Table 1) and the data showed that the average seed/grain yields were found to be $8.96,5.65$ and $32.5 \mathrm{q} / \mathrm{ha}$ of sunnhemp, horse gram and finger millet, respectively. The yield and yield attributes of sunnhemp reported in the present study are found to be low and not in accordance with those reported by Tripathi et al., (2013). This is due to lack of adoption of improved management practices like adopting spacing and nutrient management in the present study so as to keep the cultivation cost minimum, as the farmers in the zone are small and marginal farmers and considered sunnhemp as a bonus crop (Jamuna, 2018).

Similarly, the yields of horse gram are also found to be low in the present study due to lack of fertilizer application. Though, horse gram is a leguminous crop, it needs supplemented nutrients for maximum production (Umamaheswari et al., 2004). But, farmers, in general, are not applying any fertilizer to horse gram growing as contingent crop/ bonus crop as it is hardy, drought resistant legume crop (Pursegloue, 1968). It is a hardy pulse crop of semi-arid tropics that has been still considered as poor man's crop despite its high nutritional value and multifunctional use (Dorian Q. Fuller and Charlene Murphy, 2018). It is mainly grown as a late rainy season crop and hence considered as contingent crop and nutrients rich crop used for human food and animal food besides having immense medicinal value (Raghu Ram Reddy et al., 2012). Since, the horse gram is well known for its hardiness and adoptability to poor soil and adverse climatic conditions (Rajmal Suthar et al., 2017), the crop was taken up in the present study with minimal input cost so as to achieve higher net returns to suit the needs of socio-economic conditions of the zone.
The finger millet which is a traditional millet crop of North-Coastal Zone is currently gaining prominence due to awareness of nutritional importance of millets, increased health consciousness and requiring climate resilient crops under changing climate (Jamuna and Venugopala Rao, 2017). With the advent of high yielding varieties (HYV) of finger millet, there is a good scope for revitalization of millets which was evidenced in the present study by recording grain yield of $32.5 \mathrm{q} /$ ha with variety, Sri Chaitanya. The status of small millets in Andhra Pradesh as reported by Patro et al., (2016) also indicated good scope for realizing the potential yields of millets. The cost economics of rabi crops worked out (Table 2) in the present study indicated that the benefit: cost ratio was found to be more with sunnhemp (2.42:1) followed by horse gram (1.90:1 and finger millet (1.76:1). The profitability of sunnhemp was also reported by Jamuna (2018).

The highest B:C ratio in sunnhemp is due to less cultivation cost (Rs. 17,380/ha) with minimal usage of inputs, irrigation and cultivation charges when compared to that of finger millet that incurred more of cultivation cost (Rs. 36,863/ha). Similar is the reason for horse gram also for getting higher B: C ratio when compared to finger millet due to incurring less cultivation cost (Rs.11,900/ha) with minimal usage of inputs, no irrigation charges and less cultivation expenses. However, comparing the two bonus crops (horse gram/sunnhemp), the profitability was found to be more with sunnhemp due to not only its high yield potential, but also opportunity of the farmer for selling it as seed in view of high demand for green manure seed; while the produce of horse gram is being sold mostly as human and animal feed with minimal price and thereby considered it as poor man's food, despite having high nutritive value (Raghu Ram Reddy et al., 2012). 
Table.1 Yield and yield attributes of different rabi crops

\begin{tabular}{|l|c|l|c|l|c|}
\hline \multicolumn{1}{|c|}{ Sunnhemp } & \multicolumn{2}{c|}{ Horse gram } & \multicolumn{2}{c|}{ Finger millet } \\
\hline Plant height (cm) & 104.55 & Pod length $(\mathrm{cm})$ & 4.6 & Plant height $(\mathrm{cm})$ & 100.3 \\
\hline Spike length & 33.62 & No. of grains/pod & 4.7 & No. of prod. tillers/ plant & 6.9 \\
\hline No. of branches & 4.28 & No. of pods/plant & 40.0 & Ear head length $(\mathrm{cm})$ & 6.2 \\
\hline Total no. of pods/plant & 34.14 & Seed yield (q/ha) & 5.65 & Boot leaf length $(\mathrm{cm})$ & 26.6 \\
\hline Pod yield (q/ha) & 15.44 & Haulm yield (q/ha) & 8.17 & Finger length $(\mathrm{cm})$ & 5.7 \\
\hline Seed yield (q/ha) & 8.96 & & & Finger width $(\mathrm{cm})$ & 1.0 \\
\hline Shelling (\%) & 58.03 & & & Grain yield $(\mathrm{q} / \mathrm{ha})$ & 32.5 \\
\hline Stalk yield (q/ha) & 37.72 & & & Straw yield $(\mathrm{q} / \mathrm{ha})$ & 72.8 \\
\hline Harvest index (\%) & 16.85 & & & & \\
\hline
\end{tabular}

Table.2 Cost economics of different rabi crops

\begin{tabular}{|c|c|c|c|c|c|c|c|}
\hline Crop & $\begin{array}{c}\text { Yield } \\
\text { (q/ha) }\end{array}$ & Variety & $\begin{array}{c}\text { Duration } \\
\text { (days) }\end{array}$ & $\begin{array}{c}\text { COC } \\
\text { (Rs/ha) }\end{array}$ & $\begin{array}{c}\text { GR } \\
\text { (Rs/ha) }\end{array}$ & $\begin{array}{c}\text { NR } \\
\text { (Rs/ha) }\end{array}$ & B:C \\
\hline Horse gram & 5.65 & VZM 1 & 85 & 11900 & 22600 & 10700 & 1.90 \\
\hline Sunnhemp & 8.96 & SH 4 & 110 & 17380 & 42112 & 24732 & 2.42 \\
\hline Finger millet & 32.50 & VR 847 & 110 & 36863 & 65000 & 28137 & 1.76 \\
\hline
\end{tabular}

Table.3 Effect of different dates of sowing on the performance of horse gram

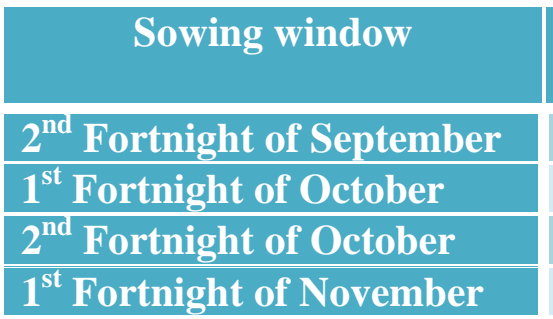

\begin{tabular}{|c|c|}
\hline $\begin{array}{c}\text { Seed yield } \\
\text { (q/ha) }\end{array}$ & $\begin{array}{c}\text { Crop duration } \\
\text { (Days) }\end{array}$ \\
\hline 3.51 & 100 \\
\hline 4.73 & 93 \\
\hline 5.65 & 85 \\
\hline 3.46 & 81 \\
\hline
\end{tabular}

Table.4 Fortnightly weather data during the crop season (Sept, 2017 to March, 2018)

\begin{tabular}{|c|l|c|c|c|c|c|}
\hline $\begin{array}{c}\text { S. } \\
\text { No. }\end{array}$ & \multicolumn{1}{|c|}{$\begin{array}{c}\text { Crop growth } \\
\text { period }\end{array}$} & $\begin{array}{c}\text { Rainfall } \\
(\mathrm{mmm})\end{array}$ & $\begin{array}{c}\text { Avg. Max. } \\
\text { Temp }{ }^{0} \mathrm{C}\end{array}$ & $\begin{array}{c}\text { Avg. Min. } \\
\text { Temp }{ }^{0} \mathrm{C}\end{array}$ & $\begin{array}{c}\text { Avg. RH } \\
\text { (FN) }\end{array}$ & $\begin{array}{c}\text { Avg. RH } \\
\text { (AN) }\end{array}$ \\
\hline 1. & $\begin{array}{l}2^{\text {nd }} \text { FN Sept'17 to } \\
2^{\text {nd }} \text { FN Dec'17 }\end{array}$ & 233.4 & 28.4 & 25.3 & 83.3 & 56.8 \\
\hline 2. & $\begin{array}{l}1^{\text {st }} \text { FN Oct'17 to } \\
1^{\text {st }} \text { FN Jan'18 }\end{array}$ & 149.6 & 27.9 & 24.0 & 82.4 & 51.5 \\
\hline 3. & $\begin{array}{l}2^{\text {nd }} \text { FN Oct'17 to } \\
2^{\text {nd }} \text { FN Jan'18 }\end{array}$ & 113.8 & 27.6 & 23.2 & 80.9 & 47.8 \\
\hline 4. & $\begin{array}{l}1^{\text {st }} \text { FN Nov'17 to } \\
2^{\text {nd }} \text { FN Jan'18 }\end{array}$ & 6.0 & 27.3 & 22.1 & 81.8 & 45.9 \\
\hline
\end{tabular}


With regard to returns, finger millet recorded higher net returns (Rs.28,137/ha) when compared to that of sunnhemp (Rs.24,732/ha) and horse gram (Rs.10,700/ha). Since, finger millet is a climate resilient crop; yield variability is less affected when compared to the crops like sunnhemp and horse gram. This was evidently reported in a study conducted for three years by Jamuna (2018) that yield variation was observed due to lot of flower drop with seasonal changes and increased pest incidence in sunnhemp.

Similarly, the performance of horse gram is also found to be highly weather dependent which was witnessed through another field study conducted on different dates of sowing on the performance of horse gram at Agricultural Research Station, Vizianagaram during rabi 2017-18.

The results of the study (Table 3 ) indicated that the early sown horse gram crop (second fortnight of September, 2017) had taken long time for maturity (100 days, respectively) due to prolonged vegetative growth with the receipt of high rainfall $(233.4 \mathrm{~mm})$ in the early stage of crop growth (September second fortnight), resulted in lower seed yield (3.51 q/ha). Even, the late sown horse gram crop (first fortnight of November, 2017) also resulted in lower seed yield $(3.46 \mathrm{q} / \mathrm{ha})$ due to less relative humidity coupled with moisture stress at the time of grain development (second fortnight of January, 2018) that caused forced maturity taking 81 days crop duration only. On the other hand, the second fortnight of October, 2017 sown crop resulted in higher seed yield $(5.65 \mathrm{q} / \mathrm{ha})$ with crop duration of 85 days due to congenial soil moisture with favourable weather parameters like rainfall, relative humidity and temperatures during the respective crop growth period (Table 4). The available literature revealed that the main causes of yield component variability are genotypic (Sadhu and Mandal, 1989), genotype by environment interactions (Shrivastava et al., 1990) and climatic variability in terms of temperature regime and moisture availability (Pala and Mazid, 1992). Hence, the study indicated the need to follow optimum date of sowing of horse gram during rabi season, even for growing it as a bonus crop, for realizing higher net benefit.

Field experiments conducted at Agricultural Research Station, Vizianagaram on "Cost effectiveness of different rabi crops in red sandy loam soils of North-Coastal Zone of Andhra Pradesh showed that the benefit: cost ratio was found to be more with sunnhemp (2.42:1) followed by horse gram (1.90:1 and finger millet (1.76:1). With regard to returns, finger millet recorded higher net returns (Rs.28,137/ha) as compared to that of sunnhemp (Rs.24,732/ha) and horse gram (Rs.10,700/ha). Since, finger millet is a climate resilient crop; yield variability is less affected when compared to the crops like sunnhemp and horse gram. This was evidently reported in another field study conducted on performance of horse gram with different dates of sowing at Agricultural Research Station, Vizianagaram during rabi 2017-18 which indicated that the early sown (Second fortnight of September, 2017) as well as the late sown (first fortnight of November, 2017) horse gram crop recorded lower yields (3.51 and 3.46q/ha, respectively) when compared to the yields recorded $(5.65 \mathrm{q} / \mathrm{ha})$ in second fortnight of October, 2017 due to congenial soil moisture with favourable weather parameters like rainfall, relative humidity and temperatures prevailed during crop growth period in October sown horse gram crop. Hence, the present study revealed good profitability with the bonus crops like sunnhemp and horse gram and higher net returns with finger millet in rabi season and the profitability of bonus crops was much influenced by weather parameters like rainfall, relative humidity and temperatures prevailed during crop growth period as witnessed in horse gram crop tested for its performance with different dates of sowing.

\section{References}

Dorian Fuller Q and Charlene Murphy. 2018. The origins and early dispersal of 
horsegram (Macrotyloma uniflorum) a major crop of ancient India. Genet Resorur Crop Evol. 65:285-305.

Gupta, S.M., Arora, S., Mirza, N., Pande, A., Lata, C., Puranik, S., Kumar, J. and Kumar, A. (2017). Finger Millet: A "Certain" Crop for an "Uncertain" Future and a Solution to Food Insecurity and Hidden Hunger under Stressful Environments. Front Plant Sci. 2017, Apr 25; 8: 643.

Jamuna, P. (2018). Profitability of rabi crops in clay loam soils of North-Coastal zone of Andhra Pradesh. Proceedings of National seminar on "Futuristic Agriculture for Sustainable Food Security" held at S.V. Ag. College, Tirupati from 21-23, February 2018.

Jamuna, P. and Venugopala Rao, N. (2017). Revitalization of millets (Ragi) through introduction of HYV and promotion in rice fallows as direct sown crop in soils of North-Coastal Andhra Pradesh. Proceedings of National Conference on "Adaptation Interventions for Climate Resilient Agriculture in Coastal Agroecosystems" held by NABARD Chair Unit, Guntur from 9-10, March 2017 at RARS, Lam Farm, Guntur.

Pala, M. and Mazid, A. (1992). On-farm assessment of improved crop production practices in North 1-/West Syria. Experimental Agriculture. Vol. 28: 175184.

Patro, T.S.S.K., Sandhya Rani, Y., Muniratnam, P., Subba Rao, M., Venugopala rao, N., Naidu, N.V. and Nageshwara Rao, T.G. (2016). Edited publication on "Status of small millets research in ANGRAU".
Pursegloue, J.W. (1968). Trop. Crops. Dicotyledons Longmans Green, London, 264P.

Raghu Ram Reddy P, Maruthi V.,Vanaja M, Reddy BMK, Jainender, Archana G, Abdul Razak SK, Maheswari $M$ and Venkateswarulu B. 2012. CRIDA 18R, a new horsegram (Macrotyloma uniflorum) variety: germination as influenced by higher $\mathrm{CO}_{2}$, temperature and relative humidity. Indian Journal of Agricultural Sciences. 82 (9): 21-23.

Rajmal Suthar, Patel, P.H., Amit Kumar and Urmila (2017). Effect of horse gram (Macrotyloma uniflorum Lam Verdec) varieties and different row spacing on yield attributes and yield. Life Sciences International Research Journal. Vol.4, Spl. Issue, Pp 1-6.

Sadhu, S.K. and Mandal, A.K. (1989). Genetic variability and character association in Chickpea (Cicer arietinum L.). Genetika (Beograd). Vol. 21: 135-139.

Shrivastava, S.K., Ram Singh and Chandrawamsi, B.R. (1990). Response of chickpea cultivars under different dates of sowing in Chhattisgarh region of Madhya Pradesh. International Chickpea News. Vol23: 26-27.

Tripathi, M.K., Babita Chaudhary., Singh, S.R. and Bhandari, H.R. (2013). Growth and yield of sunnhemp (Crotalaria juncea L.) as influenced by spacing and topping practices. African Journal of Agricultural Research. 8 (28): 3744-3749.

Umamaheswari P, Krishna Murthy SK and Yellamanda Reddy T. 2004. Response of Horsegram (Macrotyloma uniflorum (LAM) verdc) to nutrients under contingent situations in scarce rainfall zone. Agric. Sci. Digest. 24 (3):157-161.

\section{How to cite this article:}

Patro, T.S.S.K., P. Jamuna, N. Anuradha and Nagarjuna, D. 2018. Profitable rabi Crops in Red Sandy Loam Soils of North-Coastal Zone of Andhra Pradesh, India. Int.J.Curr.Microbiol.App.Sci. 7(11): 273-278. doi: https://doi.org/10.20546/ijcmas.2018.711.033 